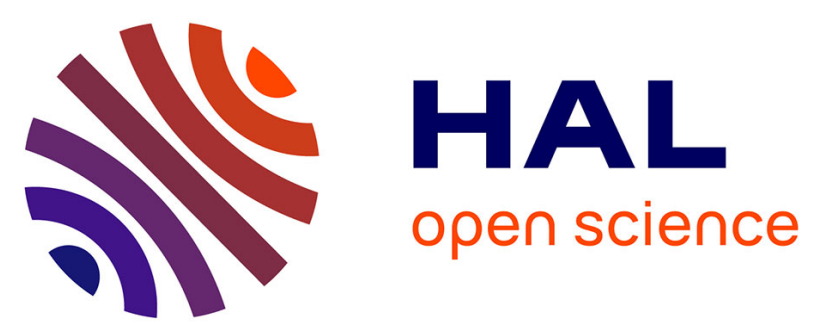

\title{
Pilot-scale study of vertical flow constructed wetland combined with trickling filter and ferric chloride coagulation: influence of irregular operational conditions
} Boram Kim, Mathieu Gautier, G Olvera, Pascal Molle, Philippe Michel, Rémy Gourdon

\section{To cite this version:}

Boram Kim, Mathieu Gautier, G Olvera, Pascal Molle, Philippe Michel, et al.. Pilot-scale study of vertical flow constructed wetland combined with trickling filter and ferric chloride coagulation: influence of irregular operational conditions. Water Science and Technology, 2015, 71 (7), pp.10881096. 10.2166/wst.2015.077 . hal-01302503

\section{HAL Id: hal-01302503 https://hal.science/hal-01302503}

Submitted on 14 Apr 2016

HAL is a multi-disciplinary open access archive for the deposit and dissemination of scientific research documents, whether they are published or not. The documents may come from teaching and research institutions in France or abroad, or from public or private research centers.
L'archive ouverte pluridisciplinaire HAL, est destinée au dépôt et à la diffusion de documents scientifiques de niveau recherche, publiés ou non, émanant des établissements d'enseignement et de recherche français ou étrangers, des laboratoires publics ou privés. 


\section{Pilot-scale study of vertical flow constructed wetland combined with trickling filter and ferric chloride coagulation. Influence of irregular operational conditions.}

Boram Kim*, Mathieu Gautier*, Grecia Olvera Palma, Pascal Molle, Philippe Michel, and Rémy Gourdon

\section{$\rightarrow$ To cite this version:}

B. Kim, M. Gautier, G. Olvera Palma, P. Molle, P. Michel, and R. Gourdon. Pilot-scale study of vertical flow constructed wetland combined with trickling filter and ferric chloride coagulation. Influence of irregular operational conditions. Water Sci. Technol. 2015, 71(7), pp 1088-1096.

Please contact the corresponding authors $(*)$ if you are interested by a copy of the article published in the journal. 
Pilot-scale study of vertical flow constructed wetland combined with trickling filter and ferric chloride coagulation. Influence of irregular operational conditions.

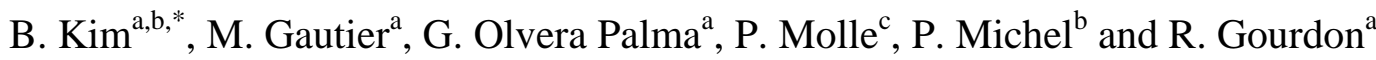

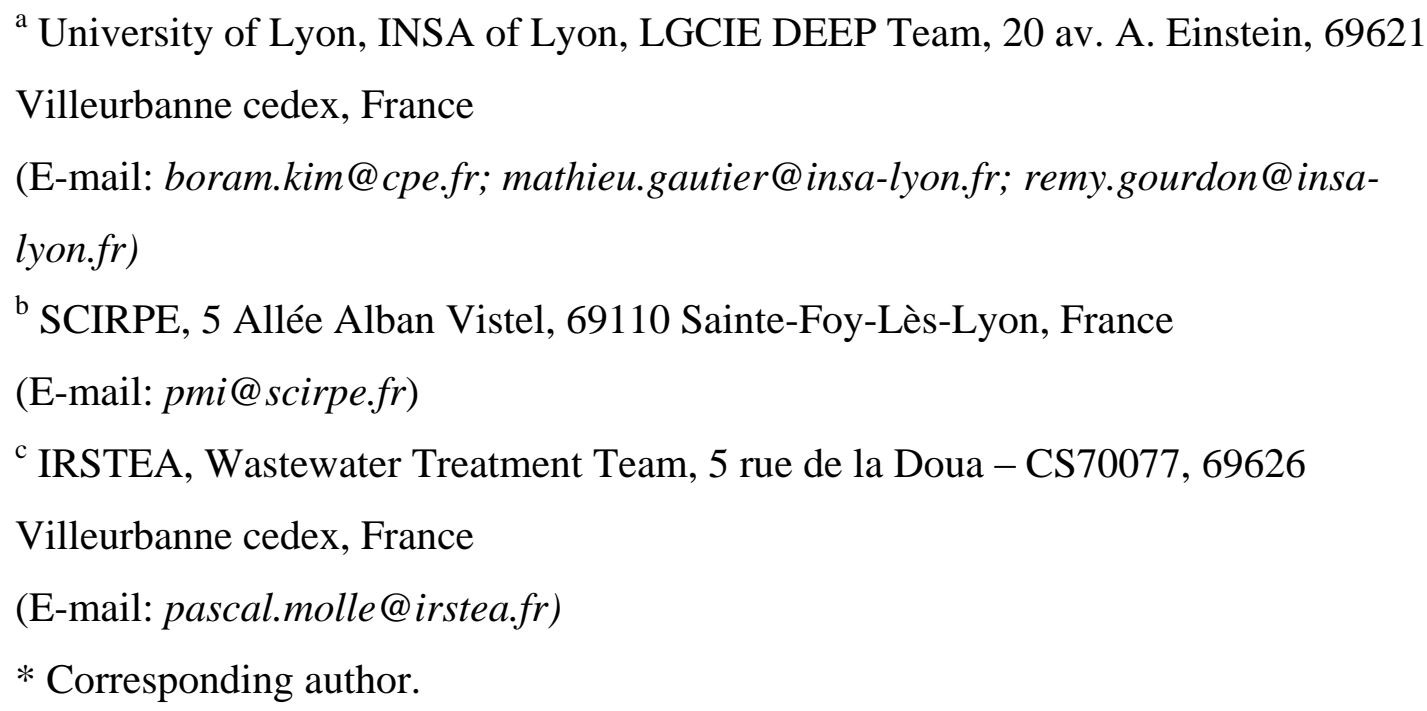




\begin{abstract}
The aim of this study was to characterize the efficiency of an intensified process of vertical flow constructed wetland having the following particularities: (i) biological pretreatment by trickling filter, (ii) $\mathrm{FeCl}_{3}$ injection for dissolved phosphorus removal and (iii) succession of different levels of redox conditions along the process line. A pilot-scale setup designed to simulate a real-scale plant was constructed and operated using real wastewater. The influences of $\mathrm{FeCl}_{3}$ injection and water saturation level within the VFCW stage on treatment performances were studied. Three different water saturation levels were compared by monitoring: suspended solids (SS), total phosphorus (TP), dissolved chemical oxygen demand (COD), ammonium, nitrate, phosphate, iron, and manganese. The results confirmed the good overall efficiency of the process and the contribution of the trickling filter pretreatment in COD removal and nitrification. The effects of water saturation level and $\mathrm{FeCl}_{3}$ injection on phosphorus removal were evaluated by analysis of the correlations between the variables. Under unsaturated condition, good nitrification and no denitrification were observed. Under partly saturated condition, both nitrification and denitrification were obtained, along with a good retention of suspended solids. Finally under saturated condition, the performance was decreased for almost all parameters.
\end{abstract}

Keywords: Vertical flow constructed wetland; Trickling filter; Ferric chloride coagulation; Phosphorus retention 


\section{INTRODUCTION}

Raw domestic wastewater treatment by vertical flow constructed wetlands (VFCW) has become very well developed in small communities in France (Molle, 2014). Numerous studies have proven the efficiency of the system in carbon removal and nitrification (Kadlec et al., 2000; Vymazal, 2002; Brix et Arias, 2005; Prochaska et al., 2007; Abou-Elela et al., 2013). Other authors introduced various alternative compact systems (Heistad et al., 2006; Prigent et al., 2013) or highlighted some limitations of VFCWs such as total nitrogen removal and poor phosphorus removal (Verhoeven and Meuleman, 1999; Prochaska et al., 2007). These possible limits may be problematic since the release of nitrates and phosphorus into sensitive aquatic ecosystems may promote eutrophication (Schindler, 1977; Lowe et Keenan, 1997; Tiessen, 2008), and therefore phosphorus (P) and total nitrogen (TN) concentrations in treated effluents must satisfy increasingly low regulatory limits.

In order to improve $\mathrm{TN}$ and $\mathrm{P}$ removal, various combined processes and tertiary treatments were developed. Hybrid systems combining vertical flow and horizontal flow (HF) constructed wetlands were investigated for $\mathrm{TN}$ removal by successive nitrification and denitrification (Vymazal, 2005; Molle et al., 2008). Good efficiencies were obtained but with increased footprint. Regarding phosphorus removal, most studies investigated systems using various filter media with high phosphorus sorption capacity (Molle et al., 2011; Vohla et al., 2011; Martín et al., 2013). Although very efficient, these approaches may not systematically provide cheap and durable solutions on a long term.

Alternative approaches were developed by the French company SCIRPE in its AZOE $^{\circledR}$ processes (EP1857419A1; WO2012150296) which are based on a treatment line which includes a trickling filter as a biological primary treatment and two successive stages of VFCW with adjustable water levels (Kim et al., 2014). This combination allows to reduce the required surface of VFCW down to a maximum of $1.5 \mathrm{~m}^{2}$ per Population-Equivalent (PE) as compared to $2 \mathrm{~m}^{2}$ in the general operational recommendations in France for classical twostage VFCWs (Molle et al., 2005). Within the $\mathrm{AZOE}^{\circledR}$ alternatives, AZOE-P ${ }^{\circledR}$ and AZOE$\mathrm{NP}^{\circledR}$ include phosphorus treatment by precipitation of dissolved reactive phosphates into particulate forms through ferric chloride $\left(\mathrm{FeCl}_{3}\right)$ injection into the outlet of the trickling filter. The particulate forms of $\mathrm{P}$ are subsequently retained by filtration though the first stage of VFCW. The deposits, which progressively accumulate at the surface of VFCW, were described by Kim et al. (2013b) and are usually removed every 10-15 years as in other 
classical French VFCWs. Contrary to AZOE-P ${ }^{\circledR}$, AZOE-NP $^{\circledR}$ includes partly saturated VFCWs to improve the total nitrogen (TN) removal. The depth of the saturated zone can be adjusted to optimize $\mathrm{TN}$ removal efficiency in AZOE-NP ${ }^{\circledR}$. Within each filtration stage, the upper zone is not saturated and therefore aerobic, whereas the lower zone is saturated with anoxic conditions allowing denitrification process to occur.

The overall performances of a full scale AZOE-NP ${ }^{\circledR}$ treatment plant was previously reported by Kim et al. (2014), showing very good removal efficiencies of carbon and total nitrogen. However, phosphorus retention was found to be more variable, around $60 \%$ of efficiency. In another study, the authors also showed that the variation of $\mathrm{pH}$ did not significantly affect phosphorus retention whereas redox potential showed much stronger effects (Kim et al., 2013a; Kim et al., 2015).

In this study, a pilot-scale AZOE-(N)P ${ }^{\circledR}$ was implemented to investigate (i) the performances of the trickling filter and ferric chloride injections, particularly in terms of phosphorus retention, (ii) the influence of irregular operational conditions of ferric chloride injections and water saturation levels within the VFCW.

\section{MATERIALS AND METHODS}

\section{Description of pilot installation}

Pilot-scale unit of AZOE-NP was installed within a greenhouse in Irstea's experimental hall located at La Feyssine in the metropolitan area of Lyon (France). Its schematic representation is shown in Figure 1. This experimental setup reproduces the operational units of a real-scale AZOE-NP plant but focused only on the first stage of filters as previous field study had shown that $\mathrm{P}$ removal mainly occurred within the $1^{\text {st }}$ stage (Kim et al., 2013a; Kim et al., 2013b; Kim et al., 2014). 


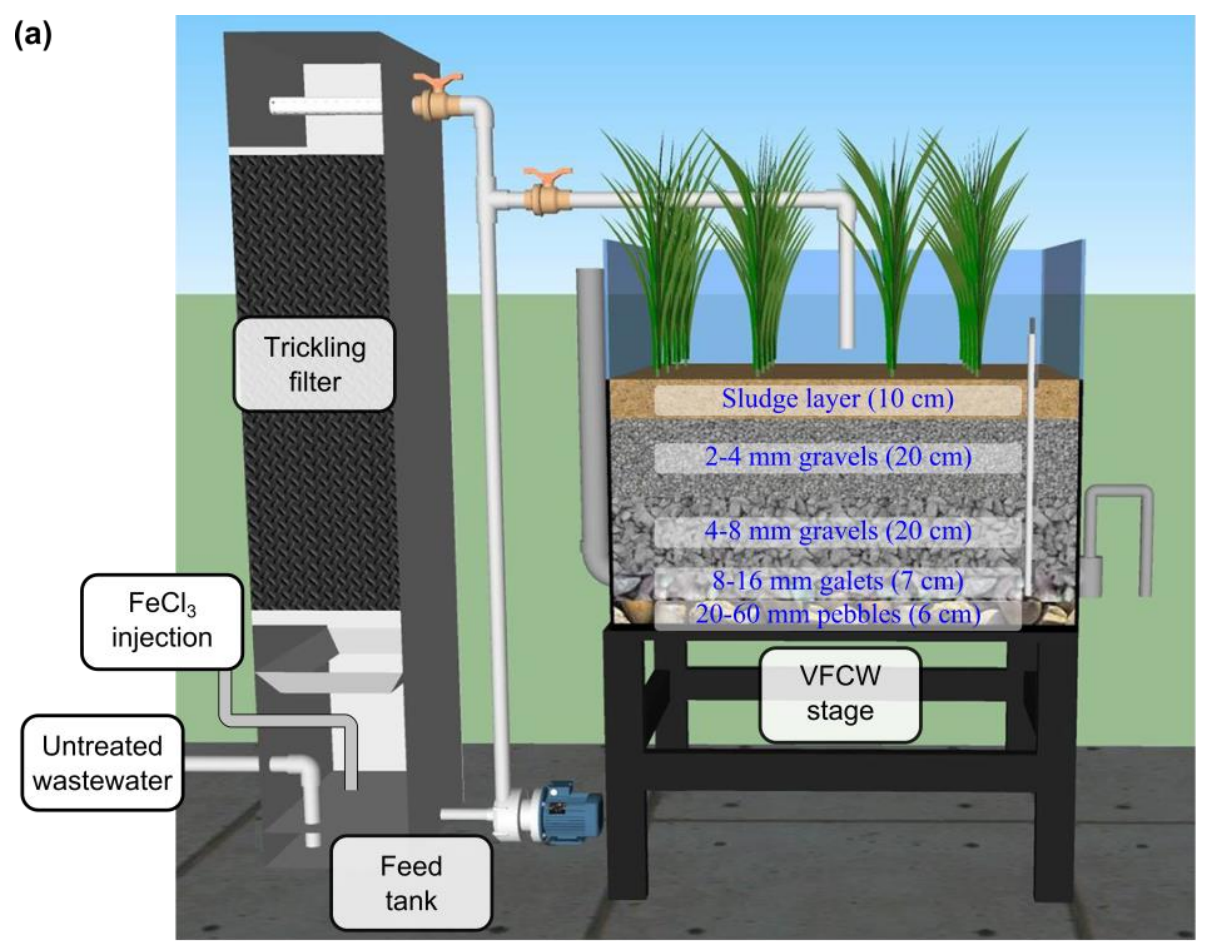

(b) Water

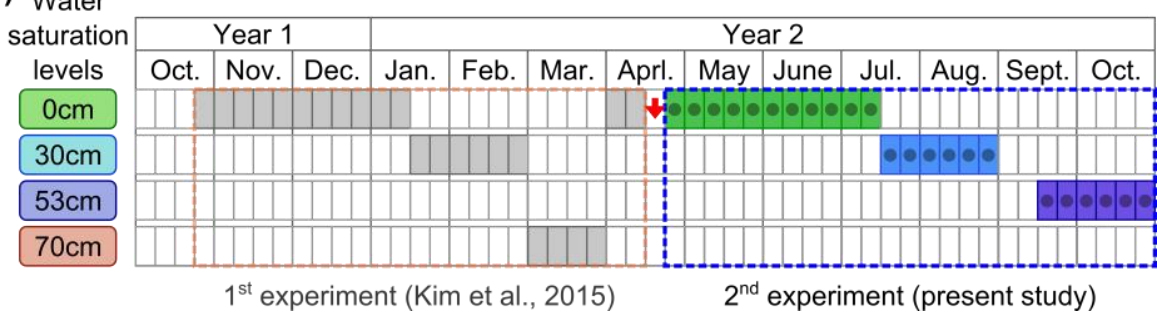

Figure 1. (a) Schematic representation of pilot-scale installation and (b) planning of experiments. The arrow symbolizes the replacement of surface sludge layer with fresh sludge at the beginning of the present study.

The pilot-scale system was designed as a combination of four sub-units as shown in Figure 1: 1) a feed tank $\left(0.24 \mathrm{~m}^{2} \times 0.38 \mathrm{~m}\right)$ used successively to collect the screened wastewaters, feed the trickling filter in a closed loop, process the mixing of ferric chloride, and feed the $1^{\text {st }}$ VFCW stage,

2) a pilot-scale trickling filter of $0.29 \mathrm{~m}^{3}$ fully packed with cross flow ordered plastic structure developing a specific surface area of $200 \mathrm{~m}^{2} \mathrm{~m}^{-3}$,

3) a dosing pump (DDE, Grundfos) for ferric chloride injection,

4) a pilot-scale VFCW with a surface of $2 \mathrm{~m}^{2}$ and a depth of $0.7 \mathrm{~m}$ equipped with a siphon to adjust the water saturation level.

The VFCW was filled with granular materials taken from a real scale AZOE-NP plant in 
operation for 8 years in order to start the experiments under mature conditions and thereby avoid phosphorus removal via adsorption onto the filter materials. Four layers were set from the bottom to the top: a $6 \mathrm{~cm}$ thick drainage layer made of $20-60 \mathrm{~mm}$ pebbles; two intermediate layers (7 cm with 8-16 mm gravels and $20 \mathrm{~cm}$ with $4-8 \mathrm{~mm}$ gravels) and a $20 \mathrm{~cm}$ upper filtration layer made of 2-4 mm gravels. The thickness of each layer was in the proportion of two thirds of the real scale. A layer of $10 \mathrm{~cm}$ of fresh surface deposit sludge (sampled from the real-scale plant) was then disposed at the top surface of the VFCW. The characteristics of the sludge deposit were described in a previous study (Kim et al., 2013b). Finally, 8 young common reeds (Phragmites australis) per square meter were planted in the surface deposit layer in April of year 1 (Figure 1, b). The rhizomes were collected at the end of the first experimental set (Kim et al., 2015) and used to seed the fresh sludge at the beginning of the present study.

\section{Operational parameters of pilot}

The pilot system was fed with real domestic wastewater obtained directly from the nearby wastewater treatment plant of La Feyssine. Wastewater was screened using a $1 \mathrm{~mm}$ sieve to reduce the risks of clogging of the distribution pipes. The pilot system was then operated automatically as described below.

Sieved wastewater was introduced into the feed tank. The feeding pump was started to feed the trickling filter downward in a closed-loop mode. Large openings in the top and bottom of the trickling filter allowed a good circulation of air though the packing medium. When a predetermined volume $(50 \mathrm{~L})$ of wastewater was reached in the pumping tank, the trickling filter's feeding was stopped. The desired volume $(7.0 \mathrm{~mL})$ of a $574 \mathrm{~g} \mathrm{~L}^{-1}$ ferric chloride aqueous solution was then precisely injected into the tank by a dosing pump, corresponding to a total added iron concentration of $0.45 \mathrm{mmol} \mathrm{L}^{-1}$ within the tank. It corresponded to the mean molar $\mathrm{Fe} / \mathrm{P}_{\text {tot }}$ ratio of 2.6 and the mean molar $\mathrm{Fe} / \mathrm{P}-\mathrm{PO}_{4}$ of 4.6 . The content of the tank was agitated by closed-loop circulation within the tank using the feeding pump $\left(1 \mathrm{~m}^{3} \mathrm{~min}^{-1}\right)$. Finally, the entire mixed liquor was spread at the surface of the VFCW pilot using the feeding pump through one feeding pipe positioned in the center of the VFCW pilot surface. Each batch represented loads of $2.8 \mathrm{~cm}$.

\section{Experimental protocol}

The whole pilot scale installation was put in operation 9 months before the beginning of this 
study. 4 months to reach stable biological conditions and 5 months to study the influence of extreme redox potential on Fe-P stability (Kim et al, 2015). During this 5 months study a continuous feeding of $0.9 \mathrm{~m}^{3}$ day $^{-1}$ with a feeding-resting cycles of $1 / 3-2 / 3$ of week was implemented to simulate the operational conditions of real-scale systems.

The first part of the study investigated the effect of ferric chloride injection on phosphorus retention. In that purpose, the injection was discontinued over 4 weeks to simulate operational malfunction. This phase was performed when the VFCW pilot was unsaturated (conditions of AZOE-P process). Then the ferric chloride injection was re-established and the pilot was subjected to the second part of the experiment dealing with the influence of three distinct saturation levels on the performance of the system, particularly total nitrogen removal and phosphorus retention. The following conditions were tested: (1) unsaturated phase $[0 \mathrm{~cm}, 6$ weeks] corresponding to a free drainage with no effluent resting at the bottom of the filter corresponding to the classical mode of operation of AZOE-P; (2) partly saturated phase [30 cm, 6 weeks] corresponding to the classical mode of operation of AZOE-NP process and (3) partly saturated phase $[53 \mathrm{~cm}, 5$ weeks] with the water level just below the sludge layer which might increase water content of the deposit layer by capillarity.

\section{Sampling and analyses}

Influent and effluent samples were taken twice a week at the beginning and the end of each feeding period of the VFCW pilot. Samples corresponded to one batch feeding. Four sampling points were monitored, namely: (i) inlet of trickling filter (sieved wastewater) [I-TF], (ii) outlet of trickling filter (before ferric chloride injection) [O-TF], (iii) inlet of VFCW (after ferric chloride injection) [I-VFCW] and (iv) outlet of VFCW stage [O-VFCW].

Each sample was immediately divided into two aliquots. The first aliquot was analyzed for total suspended solids (TSS) according to French standard methods (AFNOR, 2005). The second aliquot of each sample was immediately filtered through $0.45 \mu \mathrm{m}$ syringe filter (Sartorius Minisart). The filtrate was stored at $4{ }^{\circ} \mathrm{C}$ for a maximum of $6 \mathrm{~h}$ before being analyzed as follows. Dissolved chemical oxygen demand (dCOD) was photometrically determined after sample oxidation with a hot sulfuric solution of potassium dichromate (analogous to standard methods ISO 15705; C4/25 and C3/25 cell tests; WTW). Ammonium and nitrate were analyzed by colorimetric techniques (14739 and 114542 cell tests; WTW). Dissolved reactive phosphorus (DRP) was analyzed by the colorimetric molybdenum blue 
method (Murphy and Riley, 1962). Total phosphorus was analyzed by the persulfate digestion followed by the colorimetric molybdenum blue method. Total soluble elemental concentrations (Fe and Mn) were determined by ICP AES (Ultima 2; Horiba JobinYvon SAS) with detection limits of 0.001 and $0.001 \mathrm{mg} \mathrm{L}^{-1}$, respectively.

\section{RESULTS AND DISCUSSION}

\section{Performance of trickling filter pilot and ferric chloride injection}

Analytical results obtained from the first three sampling points (Inlet-TF, Outlet-TF and InletVFCW) are shown in Figure 2. The total number of samples analyzed was 79 and the results are therefore presented as box plots. Significant variations were observed at the inlet (untreated wastewater) for almost all parameters.

Mean input-output removal rates for dissolved COD, N-NH${ }_{4}{ }^{+}$and $\mathrm{P}_{-} \mathrm{PO}_{4}{ }^{3-}$ in the trickling filter were 51\% (SD: 16), 53\% (SD: 23), and 34\% (SD: 21), respectively. For dissolved COD, the trickling filter allowed to smooth the relatively high variation of inlet concentrations. The removal of ammonium $\left(\mathrm{N}-\mathrm{NH}_{4}{ }^{+}\right)$and production of nitrate $\left(\mathrm{N}-\mathrm{NO}_{3}{ }^{-}\right)$indicated its role in the nitrification process. Dissolved $\mathrm{P}_{-} \mathrm{PO}_{4}{ }^{3-}$ removal was also observed in the trickling filter although total phosphorus concentration remained almost constant. The dissolved phosphorus retention within this treatment step may partly be attributed to microbial consumptions within the trickling filter, and also to physicochemical sorption onto organic matters and/or residual iron species in the bottom of the pumping station. 

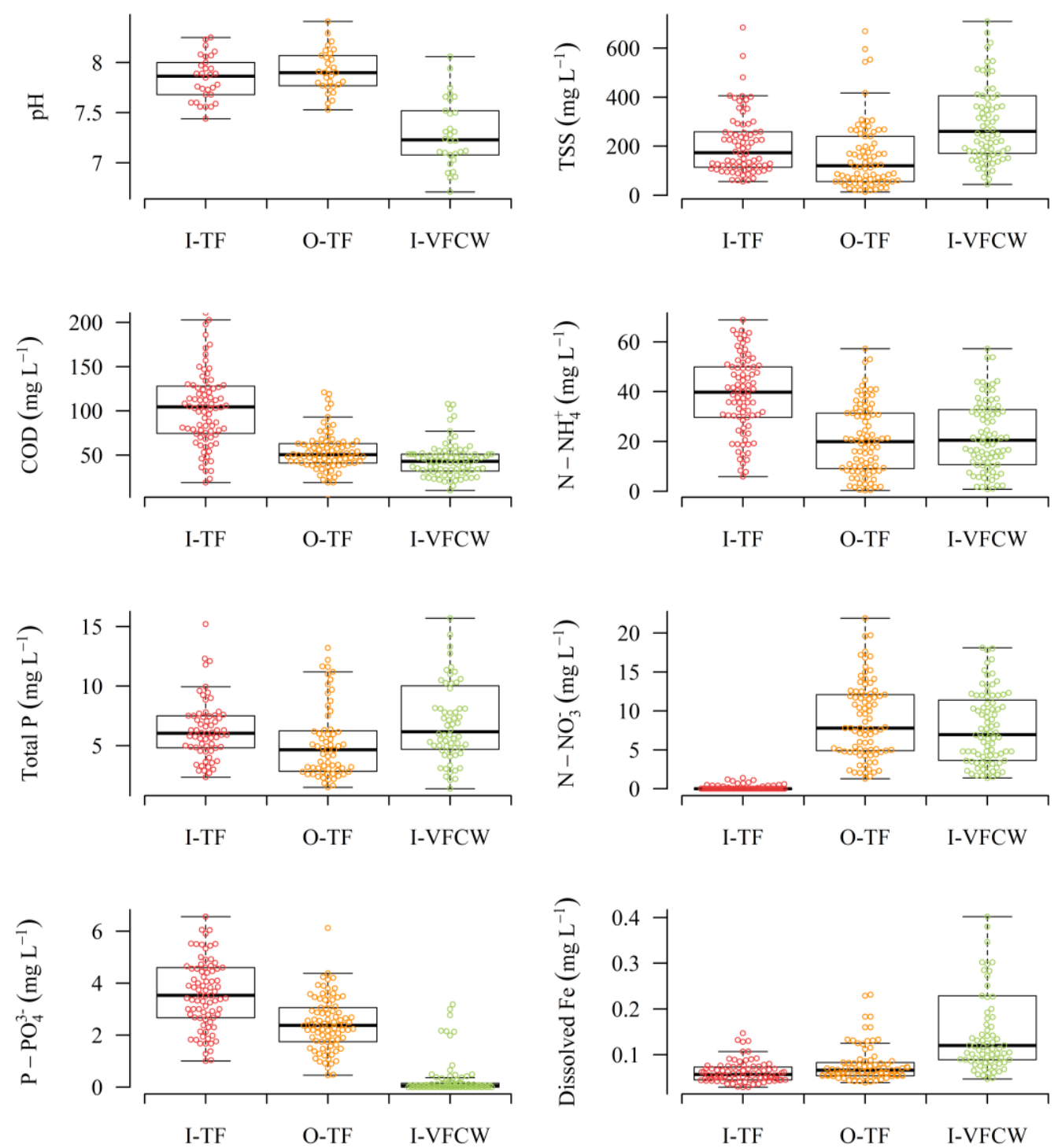

Figure 2. Monitoring of different parameters at three different points along the process line: inlet of the trickling filter (I-TF), outlet of the trickling filter (O-TF; before $\mathrm{FeCl}_{3}$ injection) and inlet of the VFCW (I-VFCW; after $\mathrm{FeCl}_{3}$ injection). The middle band, boxes and whiskers indicate the median, quartiles $\left(1^{\text {st }}\right.$ and $\left.3^{\text {rd }}\right)$, and minimum-maximum, respectively.

Ferric chloride injection showed a good performance in $\mathrm{P}_{-} \mathrm{PO}_{4}{ }^{3-}$ removal with an average of 96\% (SD: 5). Residual total dissolved iron amounts (Figure 2: at inlet of VFCW) were only $0.9 \%$ of total iron initially added. Almost all dissolved iron was therefore found to react with the reactive species during the treatment, indicating that the dosage of $\mathrm{FeCl}_{3}$ was not in large excess. 
Figure 3 shows total and dissolved phosphorus concentrations at three different treatments steps: at outlet of the trickling filter (before $\mathrm{FeCl}_{3}$ injection), at inlet of the VFCW (after $\mathrm{FeCl}_{3}$ injection) and at outlet of the VFCW.

As soon as $\mathrm{FeCl}_{3}$ was discontinued, the dissolved phosphorus concentration at inlet of the VFCW strongly increased. The release of dissolved phosphorus at the outlet of the VFCW increased progressively indicating that the retention of dissolved phosphorus was then much less effective.

As soon as the $\mathrm{FeCl}_{3}$ injection was re-established, the dissolved phosphorus concentration at inlet of the VFCW dropped near to zero. On the other hand, dissolved phosphorus concentration at the outlet of the VFCW decreased much more slowly underlining the importance of proper maintenances of the $\mathrm{FeCl}_{3}$ injection to insure good performances.

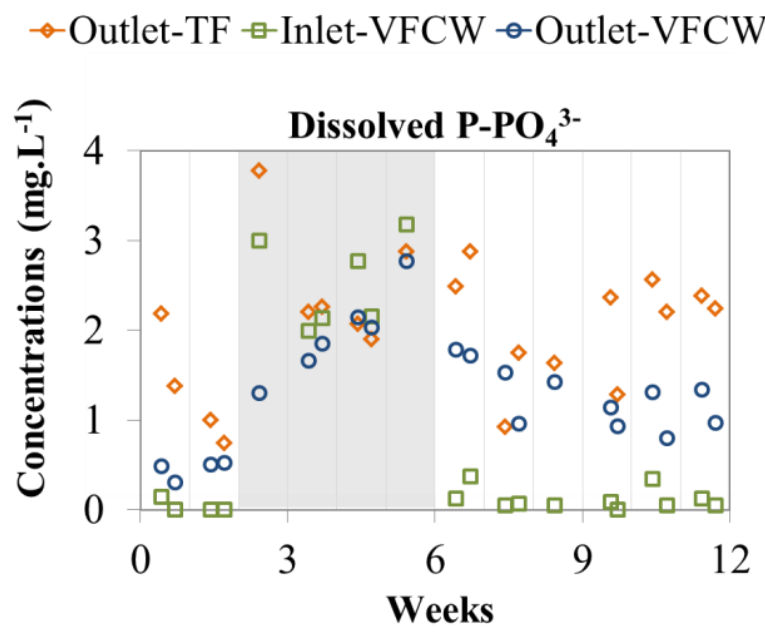

Figure 3. Concentrations of dissolved $\mathrm{P}_{-} \mathrm{PO}_{4}{ }^{3-}$ at outlet of the trickling filter and inlet/outlet of the VFCW pilot. Light grey background colour represent the experimental period simulating the dysfunction of ferric chloride injections before the inlet of the VFCW pilot.

\section{Performance of VFCW pilot dependent on the inner water saturation level}

Unlike the other treatment steps, the VFCW pilot was subjected to different environmental conditions (water saturation levels) with three different phases according to water saturation level. Inlet and outlet concentrations of SS, dissolved COD, N- $\mathrm{NH}_{4}{ }^{+}, \mathrm{N}_{-} \mathrm{NO}_{3}{ }^{-}, \mathrm{TP}, \mathrm{P}-\mathrm{PO}_{4}{ }^{3-}$, dissolved total iron $(\mathrm{Fe})$ and total manganese $(\mathrm{Mn})$ are shown in Figure 4. 
Regarding suspended solids (SS), despite high variations of inlet concentration, quite stable and low outlet concentrations were maintained throughout the successive phases of the treatment line. Outlet SS concentrations varied between $17-128 \mathrm{mg} \mathrm{L}^{-1}, 2-18 \mathrm{mg} \mathrm{L}^{-1}$, and 2$31 \mathrm{mg} \mathrm{L}^{-1}$ during the 3 successive phases, respectively. The fact that suspended solids removal was better under partly saturated than unsaturated conditions could be explained by a settling effect within the water saturated zone.

Regarding dissolved COD and ammonium, outlet concentrations varied within similar ranges under unsaturated and partly saturated conditions $\left(8-53 \mathrm{mg} \mathrm{L}^{-1}\right.$ and $0.7-10.1 \mathrm{mg} \mathrm{L}^{-1}$ respectively). On the other hand, during the last phase (water level just below the sludge layer), the outlet concentration of both dissolved COD and ammonium were found to increase, suggesting degradation of some particulate organic matters under anaerobic condition. This observation could indicate that the water saturation level just below the sludge layer was sufficient to induce a malfunctioning of the VFCW system. Two hypotheses might explain this observation: (i) the thickness of deposit layer was enough to efficiently oxidize COD and ammonia under aerobic conditions and/or (ii) capillarity water rise within the sludge layer induced anaerobic conditions in this layer.

Quite high concentrations of nitrates at the beginning of feeding periods were noted. This phenomenon was already explained by a continuous nitrification of ammonium adsorbed onto organic matters during resting period (Morvannou et al., 2014). At the very beginning of the second phase (partly saturated $30 \mathrm{~cm}$ ), high concentrations of nitrate were still observed due to the transition time for anoxic condition installation (Kim et al., 2015) in water saturated zone. From the second week of this phase, the inverse phenomenon was observed compare to the unsaturated phase: very low nitrate concentrations were observed at the beginning of feeding periods. This can be explained by the presence of anoxic zone in which the denitrification continued during the resting period. During the last phase, total nitrogen removal was unstable due to the quasi absence of nitrification and the resulting limitation of denitrification.

Finally, dissolved phosphate outlet concentration varied between $0.80-1.78 \mathrm{mg} \mathrm{L}^{-1}, 0.97$ $3.07 \mathrm{mg} \mathrm{L}^{-1}$, and $0.38-5.22 \mathrm{mg} \mathrm{L}^{-1}$ during the 3 successive phases respectively. The dissolved phosphorus and manganese concentrations increased during the partly saturated phases 
indicating the reduced condition within the water saturated zone. A previous study (Kim et al., 2015) showed that the redox condition within the VFCW pilot was strongly influenced by its inner water saturation level. When the VFCW was partly saturated, a low range of Eh values (between 0 and $-250 \mathrm{mV}$ ) were observed at the bottom of the VFCW, whereas high redox potentials remained at the top and the middle of the VFCW. Numerous studies reported the release of phosphorus by the reductive dissolution of P-bearing ferric species (Patrick et Khalid, 1974; Shenker et al., 2005; Moustafa et al., 2012; Hantush et al., 2013). On the other hand, phosphorus release was not accompanied by a stoichiometric release of iron at the outlet of VFCW pilot. This observation could suggest that the conditions within the filter induced the precipitation of solubilized iron species. For example, the presence of sulfides probably caused FeS formation as already described by other authors (Jakobsen et Postma, 1999; Erler et al., 2011; Chen et al., 2014). Indeed, due to the anaerobic conditions (Eh near to $-250 \mathrm{mV}$ ), sulfides were likely produced by sulfate reducing anaerobic bacteria. 


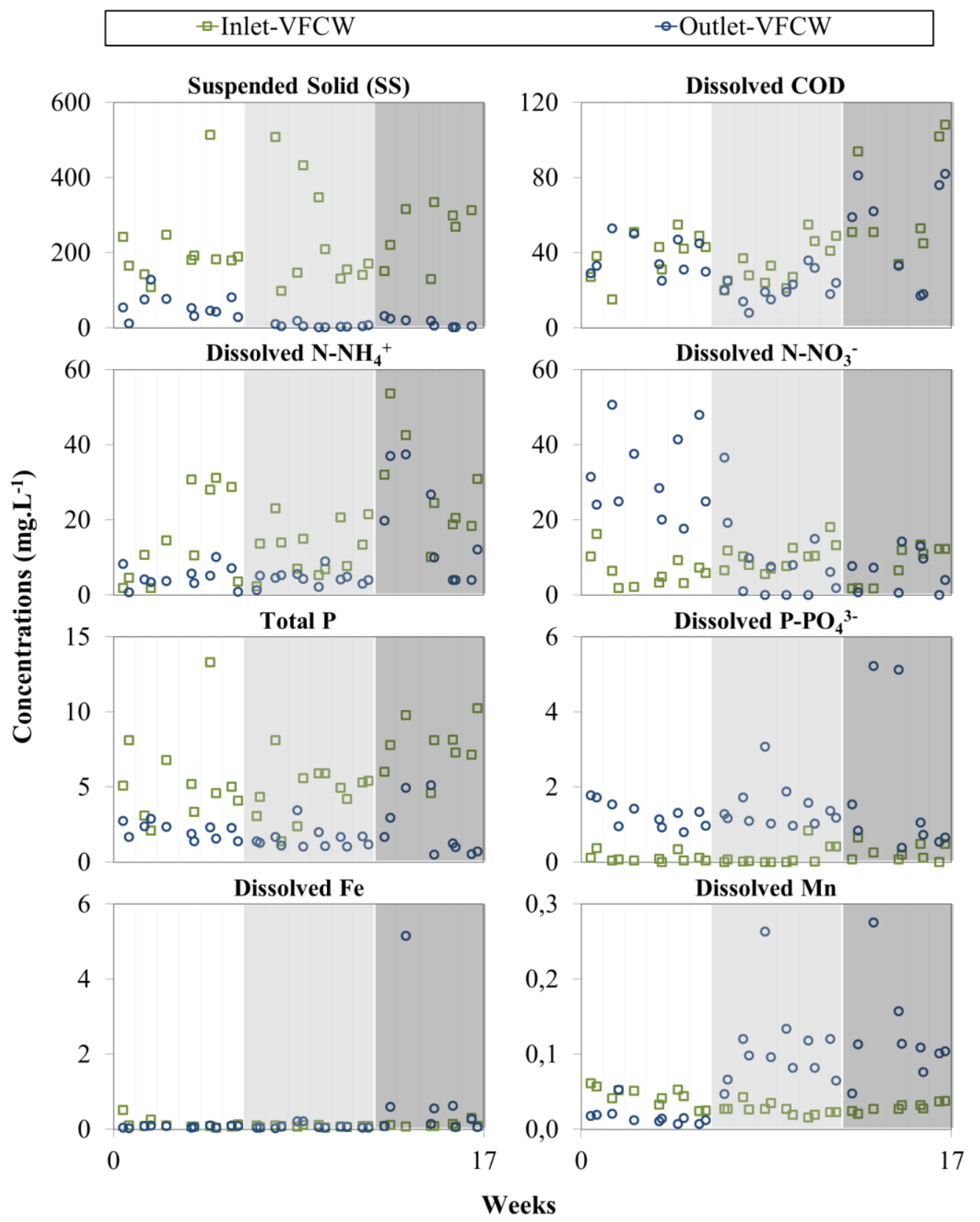

Figure 4. Concentrations of different parameters at inlet/outlet of the VFCW pilot. White, light grey and grey background colours respectively represent $0 \mathrm{~cm}\left(A Z O E-\mathrm{P}^{\circledR}\right), 30 \mathrm{~cm}$ $\left(\mathrm{AZOE}-\mathrm{NP}^{\circledR}\right)$ and $53 \mathrm{~cm}$ water saturation level within the VFCW pilot.

A principal components analysis (PCA) was performed using the $\mathrm{R}$ software in order to compare the VFCW functioning during this study to the previous experimental set performed by Kim et al. (2015). Ten relevant parameters were selected: redox potential values measured at the bottom, middle and surface of the filter, concentrations of SS, total phosphorus, dissolved COD, ammonium, nitrate, phosphate and iron at the outlet of VFCW pilot. Figure 5 shows a plot of individual data points on the plane represented by the two first principal 
component axes (accounted for $72 \%$ of the inertia). This plot revealed that those two different experimental sets showed similar VFCW functioning for $0 \mathrm{~cm}$ and $30 \mathrm{~cm}$ water saturation level. The newly tested water saturation level $(53 \mathrm{~cm})$ lied between $30 \mathrm{~cm}$ saturation groups and $70 \mathrm{~cm}$ saturation group, indicating that this water saturation level induced the intermediate condition.

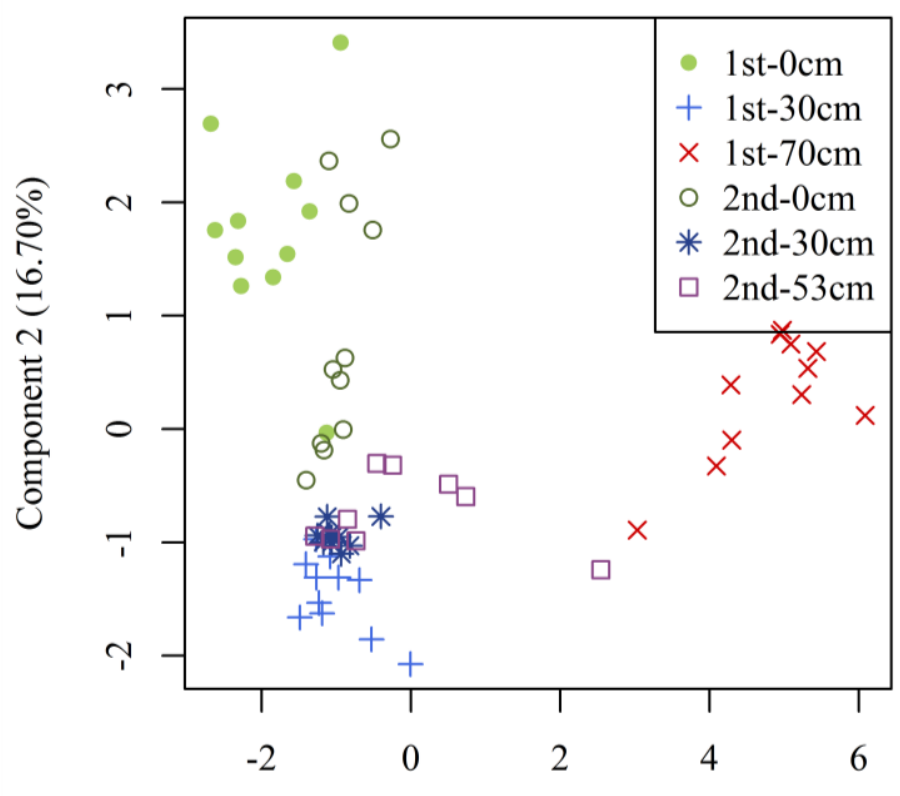

Component $1(55.32 \%)$

Figure 5. Principal component analysis (PCA) plot of individual data, illustrating two successive experimental sets: 1 st set performed with $0 \mathrm{~cm}, 30 \mathrm{~cm}$ and $70 \mathrm{~cm}$ (Kim et al., 2015); 2nd set (this study) performed with $0 \mathrm{~cm}, 30 \mathrm{~cm}$ and $53 \mathrm{~cm}$ water saturation level within the VFCW pilot.

\section{CONCLUSIONS}

This study was conducted at the pilot scale to determine the influence of operational conditions on treatment performances of different configurations of $\mathrm{AZOE}^{\circledR}$ process. $\mathrm{FeCl}_{3}$ introduced into the outlet effluent of the trickling filter reacted with dissolved $\mathrm{P}$ to transform them into particulate forms (coagulation). When the injections were discontinued, the release of dissolved $\mathrm{P}$ increased immediately. However when the injections were resumed after 6 weeks of stop, dissolved $\mathrm{P}$ outlet concentrations decreased only progressively.

Under unsaturated condition simulating AZOE- ${ }^{\circledR}$ configuration in the VFCW pilot, significant nitrification and no denitrification were noted as the VFCW pilot was under 
aerobic condition. Phosphorus in the outlet effluent was then not entirely under dissolved forms (61\% of outlet phosphorus), suggesting migration of the particulate phosphorus species through the VFCW. During second phase representing AZOE-NP ${ }^{\circledR}$ configuration, very good performances in SS removal and denitrification were observed. Nitrification did not seem to be affected by the unsaturated conditions in the VFCW. On the other hand, phosphorus in the outlet was then almost entirely under dissolved forms (about 92\% of total phosphorus), suggesting that the reduction of P-bearing ferric species induced the release of dissolved phosphorus. Finally when the water level in the VFCW pilot was set just under the sludge layer, the performances of the VFCW pilot were altered for almost all parameters.

\section{ACKNOWLEDGMENTS}

The authors wish to thank O. Collache, R. Poncet and H. Perier-Camby for the installation of the pilot system. They are also grateful to N. Dumont and D. Lebouil of LGCIE for chemical analyses (ICP-AES) and to reviewers for their contribution to improvement of this manuscript. Financial support for this work was provided by SCIRPE and CIFRE (Conventions Industrielles de Formation par la REcherche).

\section{REFERENCES}

Abou-Elela, S. I., Golinielli, G., Abou-Taleb, E. M. and Hellal, M. S. (2013) Municipal wastewater treatment in horizontal and vertical flows constructed wetlands. Ecological Engineering, 61, Part A, 460-468.

AFNOR, 2005, Recueil Normes et Réglementation Environnement., Qualité de l'eau, Vol 1 (p552), Vol 2 (p502).

Brix, H. and Arias, C. A. (2005) The use of vertical flow constructed wetlands for on-site treatment of domestic wastewater: New Danish guidelines. Ecological Engineering, 25(5), 491-500.

Chen, T.-H., Wang, J., Zhou, Y.-F., Yue, Z.-B., Xie, Q.-Q. and Pan, M. (2014) Synthetic effect between iron oxide and sulfate mineral on the anaerobic transformation of organic substance. Bioresource Technology, 151, 1-5.

Erler, D. V., Tait, D., Eyre, B. D. and Bingham, M. (2011) Observations of nitrogen and phosphorus biogeochemistry in a surface flow constructed wetland. Science of The Total Environment, 409(24), 5359-5367.

Hantush, M., Kalin, L., Isik, S. and Yucekaya, A. (2013) Nutrient Dynamics in Flooded Wetlands. I: Model Development. Journal of Hydrologic Engineering, 18(12), 17091723.

Heistad, A., Paruch, A. M., Vråle, L., Ádám, K. and Jenssen, P. D. (2006) A high- 
performance compact filter system treating domestic wastewater. Ecological Engineering, 28(4), 374-379.

Jakobsen, R. and Postma, D. (1999) Redox zoning, rates of sulfate reduction and interactions with Fe-reduction and methanogenesis in a shallow sandy aquifer, Rømø, Denmark. Geochimica et Cosmochimica Acta, 63(1), 137-151.

Kadlec, R., Knight, R., Vymazal, J., Brix, H., Cooper, P. and Haberl, R., 2000. Constructed Wetlands for Pollution Control, IWA Publishing.

Kim, B., Gautier, M., Michel, P. and Gourdon, R. (2013a) Influence du pH sur la libération du phosphore accumulé dans les boues de surface d'un filtre planté de roseaux recevant des eaux usées traitées avec du FeCl3. Déchets, Sciences et Techniques, 65, 4-11.

Kim, B., Gautier, M., Michel, P. and Gourdon, R. (2013b) Physical-chemical characterization of sludge and granular materials from a vertical flow constructed wetland for municipal wastewater treatment. Water Science \& Technology, 68(10), 2257-2263.

Kim, B., Gautier, M., Molle, P., Michel, P. and Gourdon, R. (2015) Pilot-scale experimental study of phosphorus retention in deposit layer of partly saturated vertical flow constructed wetland. Ecological Engineering. doi.org/10.101/j.ecoleng.2014.09.097.

Kim, B., Gautier, M., Prost-Boucle, S., Molle, P., Michel, P. and Gourdon, R. (2014) Performance evaluation of partially saturated vertical-flow constructed wetland with trickling filter and chemical precipitation for domestic and winery wastewaters treatment. Ecological Engineering, 71, 41-47.

Lowe, E. F. and Keenan, L. W. (1997) Managing phosphorus-based, cultural eutrophication in wetlands: a conceptual approach. Ecological Engineering, 9(1-2), 109-118.

Martín, M., Gargallo, S., Hernández-Crespo, C. and Oliver, N. (2013) Phosphorus and nitrogen removal from tertiary treated urban wastewaters by a vertical flow constructed wetland. Ecological Engineering, 61, Part A, 34-42.

Molle, P. (2014) French vertical flow constructed wetlands: a need of a better understanding of the role of the deposit layer. Water Science and Technology, 69(1), 106-112.

Molle, P., Liénard, A., Boutin, C., Merlin, G. and Iwema, A. (2005) How to treat raw sewage with constructed wetlands: an overview of the French systems. Water Science \& Technology, 51(9), 11-21.

Molle, P., Martin, S., Esser, D., Besnault, S., Morlay, C. and Harouiya, N. (2011) Phosphorus removal by the use of appatite in constructed wetlands: Design recommendations. Water Practice \& Technology, 6(3).

Molle, P., Prost-Boucle, S. and Lienard, A. (2008) Potential for total nitrogen removal by combining vertical flow and horizontal flow constructed wetlands: A full-scale experiment study. Ecological Engineering, 34(1), 23-29.

Morvannou, A., Choubert, J.-M., Vanclooster, M. and Molle, P. (2014) Modeling nitrogen removal in a vertical flow constructed wetland treating directly domestic wastewater. Ecological Engineering, 70, 379-386.

Moustafa, M. Z., White, J. R., Coghlan, C. C. and Reddy, K. R. (2012) Influence of hydropattern and vegetation on phosphorus reduction in a constructed wetland under high and low mass loading rates. Ecological Engineering, 42, 134-145.

Murphy, J. and Riley, J. P. (1962) A modified single solution method for the determination of phosphate in natural waters. Analytica Chimica Acta, 27(0), 31-36. 
Patrick, W. H. and Khalid, R. A. (1974) Phosphate Release and Sorption by Soils and Sediments: Effect of Aerobic and Anaerobic Conditions. Science, 186(4158), 53-55.

Prigent, S., Belbeze, G., Paing, J., Andres, Y., Voisin, J. and Chazarenc, F. (2013) Biological characterization and treatment performances of a compact vertical flow constructed wetland with the use of expanded schist. Ecological Engineering, 52, 12-18.

Prochaska, C. A., Zouboulis, A. I. and Eskridge, K. M. (2007) Performance of pilot-scale vertical-flow constructed wetlands, as affected by season, substrate, hydraulic load and frequency of application of simulated urban sewage. Ecological Engineering, 31(1), 57-66.

Schindler, D. W. (1977) Evolution of Phosphorus Limitation in Lakes. Science, 195(4275), 260-262.

Shenker, M., Seitelbach, S., Brand, S., Haim, A. and Litaor, M. I. (2005) Redox reactions and phosphorus release in re-flooded soils of an altered wetland. European Journal of Soil Science, 56(4), 515-525.

Tiessen, H., 2008. Phosphorus in the global environment. The Ecophysiology of PlantPhosphorus Interactions. P. J. White and J. P. Hammond, Springer Netherlands: 1-7.

Verhoeven, J. T. A. and Meuleman, A. F. M. (1999) Wetlands for wastewater treatment: Opportunities and limitations. Ecological Engineering, 12(1-2), 5-12.

Vohla, C., Kõiv, M., Bavor, H. J., Chazarenc, F. and Mander, Ü. (2011) Filter materials for phosphorus removal from wastewater in treatment wetlands-A review. Ecological Engineering, 37(1), 70-89.

Vymazal, J. (2002) The use of sub-surface constructed wetlands for wastewater treatment in the Czech Republic: 10 years experience. Ecological Engineering, 18(5), 633-646.

Vymazal, J. (2005) Horizontal sub-surface flow and hybrid constructed wetlands systems for wastewater treatment. Ecological Engineering, 25(5), 478-490. 